\title{
«ВОЕННА ІСТОРІЯ ЗОВСІМ НЕ МАЕ СВОЇМ ЗАВДАННЯМ ОСУДЖУВАТИ». ВОЛОДИМИР САЛЬСЬКИЙ: ВІД РОЗУМІННЯ МЕТОДОЛОГІЇ ІСТОРІЇ ДО ПРОБ НА НАУКОВІЙ НИВІ
}

\begin{abstract}
Анотація: Проаналізовано трансформацію поглядів визначного українського військового та політичного діяча Володимира Сальського щодо розуміння методології історії та еволюиію його проб на науковій ниві. Стверджується, що до сьогодні збереглися дуже иінні нотатки, які дають можливість судити про В. Сальського як науковия. Вказано, що йдеться про критичні зауваження на книгу його сучасника, який також брав активну участь у бойових діях проти більшовиків на території України у 1919 р., М. Капустянського, написані у червні 1922 р. Розглянуто низку публіцистичних праць В. Сальського, присвячених історичним дослідженням. Зроблено висновок, що В. Сальський окрім блискучої політичної та військової кар'єри, відзначився як $і$ чудовий науковець та публіцист, критичний дослідник, фахівець з методологї̈ історії та хороший аналітик як процесів у минулому, так і тих подій, учасником яких він був безпосередньо.
\end{abstract}

Ключові слова: Володимир Сальський, воєнна історія, методологія історії, наукова спадщина

У першій половині XX ст., у період доленосних історичних змін, насичених бурхливими подіями: війнами, політичними протистояннями, змінами режимів, зростає зацікавлення історичними наративами. Чимало громадських, політичних і військових діячів, усвідомлюючи, в який важливий час їм довелося жити, прагнуть долучитися до історії. Вони є авторами різного роду мемуарної літератури, в яких відображають події, очевидџями яких були. Чимало громадських й особливо військових функщіонерів пробували свої сили й у царині історичної науки. Це, зокрема, М. Капустянський ${ }^{1}$, О. Доценко ${ }^{2}$, М. Омелянович-Павленко ${ }^{3}$, В. Прохода ${ }^{4}$ тощо. Їхнім працям властива спільна характерна риса - вони, здебілышого, мають науково-публіцистичномемуарний характер. Адже автори були очевидцями тих подій, які описують у своїх дослідження. Тому білышість таких праць позначені долею субєктивізму. Втім, цінність їх для історичної науки, особливо історії України початку XX ст., вкрай важлива. Сукупно вони дають можливість

\footnotetext{
* Каменщев Денис Сергійович - здобувач кафедри гуманітарних наук, Національна академія сухопутних військ імені гетьмана Петра Сагайдачного (м. Львів, Україна);

ORCID: https://orcid.org/0000-0003-2115-6197; email: d.kamentsev2020@gmail.com

${ }^{1}$ Капустянський М. Похід Українських Армій на Київ - Одесу в 1919 році (Короткий воєнно-історичний огляд). У 2-х кн. Мюнхен, 1946.

${ }^{2}$ Доценко О. Літопис Української Революції. Матеріяли й документи до історії Української Револющії. Т. II, кн. 4. Київ-Львів, 1923. 364 с.

${ }^{3}$ Омелянович-Павленко М. На Україні 1919. Переговори й війна з російською добровольчою армією. Прага, 1940. 96 c.

${ }^{4}$ Прохода В. Записки непокірливого. Книга II: На чужині. Національно-культурна діяльність, боротьба за існування й перебування «на дні життя». Новий Ульм, 1972. 364 с.
} 
відтворити цілісну картину подій Національної революції 1917-1921 рр., особливо перебіг бойових дій на фронтах у протистоянні з більшовиками та денікінською армією, навіть виявити роль особового фактору у розгортанні воєнних операцій тощо.

Одним із визначних українських військових і політичних діячів початку ХХ ст., який пробував свої сили в історичній науці, був командуючий Запорізькою групою, згодом - усією Дієвою армією УНР, міністр військових справ УНР у 1919-1920 та 1924-1940 рр., генералхорунжий Володимир Петрович Сальський (1885-1940), постать якого практично не досліджена в історіографії. Фактично його діяльність досі аналізувалась епізодично - на загальному тлі Української революції 1917-1921 рр., зокрема, у контексті розвитку українських збройних сил того часу. Йдеться про наукові розвідки С. Коваленка ${ }^{5}$, М. Литвина та К. Науменка ${ }^{6}$, Я. Тинченка ${ }^{7}$.

Мета статті полягає у відтворенні на основні публіцистичної та мемуарної спадщини Володимира Сальського трансформацію його поглядів щодо розуміння методології історії та еволющію його проб на науковій ниві.

Володимир Петрович Сальський походив 3 дворянської родини 3 м. Острог ${ }^{8}$. Здобув військову освіту у Віленському піхотному юнкерському училищі, а згодом у Воєнній академії Генерального штабу в Петербурзі, яку закінчив 1912 р. 3 відзнакою. Він був одним 3 кращих випускників цього освітнього закладу. За особливі заслуги у навчанні В. Сальський був нагороджений срібною медаллю, а його ім'я було занесене на мармурову дошку академії Генерального штабуํ. Брав участь у Першій світовій війні, воюючи на Північному фронті. Зокрема був старшим адютантом оперативного відділу штабу 12-ї армії в Прибалтиці ${ }^{10} .3$ початком Української національної революції В. Сальський, як прихильник ідеї побудови незалежної України, брав активну участь в українізації військових частин. За часів УНР, Гетьманату і Директорії у боях з більшовиками обстоював самостійність України. В. Сальський завдяки своєму професіоналізму, хоробрості, незмінності поглядів і переконань здобув щиру повагу і великий авторитет серед солдатів та офіцерів.

Збереглися дуже цінні нотатки, які дають можливість судити про В. Сальського як науковця. Це - критичні зауваження на книгу його сучасника, який також брав активну участь у бойових діях проти білышовиків на території України у 1919 р., М. Капустянського. Написані у червні 1922 р. вони є своєрідною рецензією на дослідження «Похід Українських Армій на Київ - Одесу в 1919 році (Короткий воєнно-історичний огляд)». Білышість зауважень В. Сальського стосуються тих чи інших тверджень М. Капустянського про дії Запорізької групи армій під час боїв на Проскурівському напрямі.

\footnotetext{
${ }^{5}$ Коваленко С. Чорні запорожці: історія полку. 2-ге видання. Київ: Видавництво «Стікс», 2015. 368 с.

${ }^{6}$ Литвин М.P., Науменко К.Є. Збройні сили України першої половини XX ст. Генерали та адмірали / Інститут українознавства імені І. Крип'якевича НАН України. Львів; Харків: «Видавництво Сага», 2007. 244 с.

${ }^{7}$ Тинченко Я.Ю. Офіщерський корпус Армії Української Народної Республіки (1917-1921). Київ: Темпора, 2007. Кн. 1. 535 с.; Тинченко Я.Ю. Офіцерський корпус Армії Української Народної Республіки (1917-1921). Київ: Темпора, 2007. Кн. 2. 2011. 422 с.

8 50-тиліття Генерала В. Сальського. Гуртуймося. 1935. Ч. II-III (XIV-XV). С. 7.

${ }^{9}$ Лозинський А.Ф. Українці в системі кадрового забезпечення сухопутних військ збройних сил Російської імперії наприкінці XIX - на початку XX ст. Військово-науковий вісник (Львів). 2017. Вип. 27. С. 52.

${ }^{10}$ Колянчук О., Литвин М., Науменко К. Генералітет Українських визвольних змагань. Біограми генералів та адміралів українських військових формацій першої половини XX століття. Львів, 1995. С. 232.
} 
Водночас спогади ілюструють розуміння автором методології історії. В. Сальський усвідомлював важливість цієї наукової галузі у переломні моменти життя суспільства, народу, людства загалом. Адже вона дозволяє не лише встановити причинно-наслідкові зв'язки подій і процесів, зрозуміти їх суть, природу соціальних чи політичних рухів, ідеологій, а й виконує важливу для соціуму прогностичну функцію. Також у спогадах В. Сальський неодноразово наголошував на основних принципах, яких неодмінно повинен дотримуватись будь-який історик. Особливо важливим він вважав принцип об’єктивності. Тим паче при дослідженні військової проблематики, бо «воєнна історія єсть власне основне джерело воєнних знань»". Найскладніше, за твердженням В. Сальського, писати історію тоді, коли автор є безпосереднім учасником подій, які висвітлює. За таких умов дотримуватись принципу об'єктивності викладу дуже складно. Автор завжди буде певною мірою упереджений. А тим паче, якщо він відповідальний за прийняття доленосних рішень у ході бойових дій. У своїх спогадах В. Сальський критикує М. Капустянського саме за надто суб’єктвні твердження, крайню деталізацію подій і відсутність загальної картини, подекуди помилковість зроблених висновків ${ }^{12}$.

На думку В. Сальського, головне для того, хто вивчає історію, «обєєктивно змалювати все, як було насправді: на підставі яких даних приймалось те чи інше рішення, яка обстановка була в дійсності, як дане рішення провадилось і до чого привело» ${ }^{13}$. У військовій історії досліднику слід обмежитись лише констатацією фактів, у жодному разі не осуджуючи та не схвалюючи. Історик, насамперед, повинен бути неупередженим, відкинути будь-які симпатії/антипатії, суб'єктивний досвід при оцінці подій, політиків, військових діячів тощо, залучивши при цьому якнайбільшу кількість джерел, що висвітлюють проблему різнобічно та максимально всеохоплююче. Коли ж дослідник стикається із браком матеріалів, то, за твердженням В. Сальського, повинен «обмежитись лише викладом усталених фактів».

Якщо автор при цьому робить наукові висновки, то повинен дотримуватись певних умов, щоб позбутись суб'єктивізму й упередженості. На думку В. Сальського, висновки у науковому дослідженні поділяються на два види: зроблені на основі всеохоплюючих і різнобічних джерел, детально перевірених даних, та такі, що базуються на неповних даних, але $є$ необхідними для більш загального, контекстуального розуміння подій і процесів.

Обов'язковим елементом будь-якого історичного твору, що підкреслював його науковий характер, вважав примітки. Цьому елементу історичної праці В. Сальський приділив особливу увагу. Вони дозволяють конкретизувати інформацію, розглянути альтернативний до авторського погляд на події, розширити історичне тло процесів та явищ тощо. Натхненний лекціями свого учителя ще з Воєнної академії Генерального штабу, генералполковника М. Юнаківа, постійно наголошував на особливій важливості приміток у нау-

\footnotetext{
${ }^{11}$ Сальський В. 3 історії операцій Запорізької групи армії УНР влітку 1919 р. Військово-історичний альманах, 2010. № 2. C. 123-124.

${ }^{12}$ Ibid. C. 124.

${ }^{13}$ Ibid. C. 123.

" Юнаків Микола Леонтійович (1871-1931) - український військовий і громадсько-політичний діяч, генералполковник. Крім військової кар'єри значну увагу приділяв науковій і викладацькій роботі. Досліджував історію Північної війни, особливо воєнні операції швецької армії на українських землях у 1708-1709 pp. У 1907 р. після успішного захисту дисертації («Похід Карла ХІІ в Україну в 1708-9 роках»), був призначений екстраординарний професором у Воєнній академії Генштабу в Петербурзі. Згодом очолював кафедру російської воєнної історії.
} 
ковому дослідженні. У спогадах В. Сальський цілковито підтримав твердження педагога про пріоритетність цього елементу історичного твору, його винятковість в об'єктивному висвітленні подій: «примітки з посилками на підстави висновків і оцінок (які можуть бути суперечні) часто мають більше наукове значення і мають більше місця, ніж самий виклад» ${ }^{14}$ Такий підхід до написання історичного твору посилює відповідальність у роботі дослідника, застерігає від поспішних і не завжди достатньо аргументованих висновків, водночас полегшує наукові пошуки послідовників, які у світлі нових джерел можуть конкретизувати чи навіть спростовувати думки попередників. Увага до приміток також на користь майбутньому читачеві наукового твору. Вони вберігають від безоглядної довіри автору, його оцінок подій чи явищ, спонукаючи до критичного осмислення матеріалу та самостійних виважених висновків.

Саме ці недоліки історичного дослідження, на думку В. Сальського, характерні праці М. Капустянського. Розмірковуючи над тим, яку позицію обрав автор, він зауважує, що все ж «активний учасник переміг історика». Тому твір, попри його історичне значення, хибує суб’єктивізмом. 3 цього приводу В. Сальський зауважив: «Як у активного учасника, у автора склались під час його діяльності деякі враження і погляди (помилкові через незнання всієї обстановки на місцях); але як історик автор не зміг в деяких випадках зібрати всі приступні йому дані і прийти до інших поглядів, себто відмовитись від того, що в ньому вже твердо уклалося» ${ }^{15}$.

Щире зацікавлення Володимира Петровича історичною наукою знайшло відображення і в низці його публіцистичних праць. Так, у статті «Про оборону наших північних кордонів» ${ }^{16}$, він виступає знавцем історії військового протистояння Франції та Німеччини, зокрема детально аналізує збройні конфлікти цих країн від середньовіччя до Першої світової війни. У публікації постає як відмінний військовий теоретик і знавець історії воєн. Відштовхуючись від досвіду французько-німецького багатовікового протистояння, він розглядає роль природних кордонів в обороноздатності України. Автор аргументовано спростовує значення ландшафтно-географічного фактора у стратегії ведення бойових дій, особливо з розвитком інженерної справи, технології зброярства та військового мистецтва. Особливо він відкидає твердження деяких військових теоретиків про вирішальну роль наявності/відсутності природних кордонів в обороноздатності країни. Рішуче заперечує думку про те, що брак чітких ландшафтних бар'єрів на українсько-російському прикордонні - це «доказ того, що Україна не може існувати як самостійна держава, окремо від Росії» ${ }^{17}$. На думку В. Сальского, на початку XX ст. природний фактор суттєво поступається інтелектуальній складові воєнних дій. Тому кожна держава повинна вибудовувати чітку стратегію оборони, продумуючи до найменших дрібниць усі можливі небезпеки й загрози у близькій, і навіть далекій перспективі. А з огляду на хиткість паритету сил у сучасній міжнародній політиці, ця проблема - одна з найактуальніших для кожної держави. Запорука успіху у війні - готовність до неї. В. Сальський наголошував, що «Військова сила, як

\footnotetext{
${ }^{14}$ Сальський В. 3 історії операцій Запорізької групи... С. 123.

${ }^{15}$ Ibid.C. 124.

${ }^{16}$ Сальський В. Про оборону наших північних кордонів. Тризуб. 1925. Ч. 7.; Сальський В. Про оборону наших північних кордонів. Тризуб. 1925. Ч. 8.

${ }^{17}$ Сальський В. Про оборону наших північних кордонів. Тризуб. 1925. Ч. 7. С. 9.
} 
всяка сила, шукає виходу своїй енергії в напрямі найменшого опору, цебто, де найменше перешкод, але далеко не завжди поняття перешкоди з погляду військового, ототожнюється 3 поняттям природньої перешкоди. Воєнна вартість природніх кордонів залежить від багатьох обставин, а в першу чергу від підготовки та організації держави до власної оборони» ${ }^{18}$.

У статті «Старі мрії і нові пісні» проявляється інтерес В. Сальського до історії Польщі, зокрема періоду Першої Речі Посполитої, коли українські, білоруські та литовські землі увійшли до складу цього державного утворення. Він з наукових позицій намагається проаналізувати доцільність та актуальність пропагування у сучасних міжнародних політичних відносинах т. зв. ягеллонської ідеї. Особливо його хвилює доля національних меншин, їх боротьба за свої права. В. Сальський наголошує, що сформована ще у середньовіччі ягеллонська ідея із відновленням польської державності втратила свою актуальність. Реалії XX ст. вимагають створити нову ідею, яка б врахувала прагнення національних меншин, усувала гегемонію однієї нації над іншою. Насамперед, це порозуміння 3 «українською нацією, яка неповстриманно прямує до здійснення свого національного ідеалу - незалежної державности. Першим же кроком на цьому шляху є унормування стосунків 3 українською меншістю, що перебуває в Польщі» ${ }^{19}$.

Зрештою, В. Сальський не лише мав власне розуміння методології історії, він спробував здійснити свій вклад в історичну науку.

Зрозуміло, що обіймаючи посаду міністра військових справ, змушений був вирішувати нагальні державні справи, а тому часу на повноцінну наукову роботу було вкрай мало. Однак він розумів необхідність збереження для майбутнього пам'яті про події Української національної революції 1917-1921 рр. А особливо - неупередженого погляду на них. В. Сальський надавав великої ваги історичним джерелам при написанні наукового дослідження. Вважав головним завданням вченого залучити якомога більше матеріалів, здійснити усесторонній, максимально об’єктвний аналіз подій, процесів і явищ. Тому свої проби на науковій ниві зосередив саме у царині джерелознавства.

В. Сальський спільно з генералом П. Шандруком видав збірку оперативних документів Штабу армії УНР під назвою «Українсько-московська війна 1920 року в документах», що побачила світ 1933 р. у друкарні НТШ у Львові. У книзі вміщено документи виразно обмеженого хронологічного відтинку - літо-осінь 1920 р. Вони охоплюють події на Україні після повернення армії УНР із «зимового походу» (6 травня 1920 р.), період спільних операцій з військами Другої Речі Посполитої до поразки, переходу за р. Збруч та інтернування на території Польщі (21 листопада 1920 р.). Такий підбір матеріалів, очевидно, пов'язаний $з$ тим, що саме ці документи набули чинності під час перебування В. Сальського на посаді міністра військових справ. Більшість із них вдалося офіційними/неофіційним особам перевезти на польські землі після переходу кордону.

У передмові до книги В. Сальський зауважив, що робота над укомплектуванням джерел була тривалою та кропіткою. Зокрема, він писав: «Збірка і впорядкування цих документів тривала кілька років, бо приходилося їх збирати з ріжних справ (т. зв. «діла»)

\footnotetext{
${ }^{18}$ Ibid.C. 11.

${ }^{19}$ Сальський В. Старі мрії і нові пісні. Тризуб. 1926. Ч. 26.

'В. Сальський також був редактором видання, а ще автором передмови до нього.
} 
ріжних штабів і від окремих осіб, яким за надіслання документів належить подяка та щире признання. Малося на увазі зібрати всі документи, що містили дані про ворога, свої сили й засоби, оцінку Армійським Командуванням ситуації та його оперативні накази, директиви, зарядження і т. п.» ${ }^{20}$. Особливу історичну цінність мають розвідувальні дані окремих частин армії УНР, зокрема, Запорізької, Волинської, Київської, Херсонської дивізій та інших військових підрозділів.

Водночас В. Сальський наголошує на відсутності цілого масиву джерел, які просто втратили під час військових дій чи відступу на територію Польщі. Це: директиви Головного отамана, Ради міністрів і Начальної команди польських військ до Командування армією УНР, щоденник воєнних дій, дані про морально-психологічний стан вояків тощо.

У передмові генерал окреслив головні завдання, які упорядники передбачали реалізувати при впорядкуванні цього видання. По-перше, «врятувати документи від руйнуючого діяння часу (вицвітання, тління паперу і т.п.)». Він усвідомлював, що несприятливі матеріально-побутові умови перебування на еміграції (брак відповідного приміщення, недотримання температурного режиму, вологості, зміна локацій) часто були ключовим фактором, що прискорював фізичне руйнування джерел. Тому видання було покликане запобігти остаточному знищенню документів.

Друге завдання, яке прагнули реалізувати упорядники, - заохотити колишніх військових чи цивільних осіб, яким вдалося зберегти якісь матеріали про хід воєнних дій в Україні, оприлюднити їх. Також спонукати до видання дивізійні, полкові, курінні збірники документів. Адже їх значення для майбутніх дослідників воєнної історії було б безцінним.

Третє завдання, яке реалізували видавці, - популяризація документів, оприлюднення їх перед широким загалом. Це дозволило б кожному, хто цікавиться історією, не перебувати у полоні чиїхось суджень, насамперед авторів наукових творів чи спогадів, а сформувати власне неупереджене бачення проблеми, події чи явища.

На думку В. Сальського, доступ до першоджерел у перспективі також спонукатиме учасників подій 1917-1921 рр. писати власні мемуари, базуючись на офіційних документах, що певною мірою гарантуватиме дотримання принципу об'єктивності при викладі фактів. Водночас генерал зауважив, що чи не найбілыша проблема його сучасників - бути неупередженим при оцінюванні подій, стратегій і тактик командування: «Відомо, що найтяжче писати історію тим, що робили її, i, на жаль, доводиться ствердити, що властива кожній воєнно-історичній праці критична аналіза подій та поступовання учасників цих подій розростається внаслідок понесеної поразки до необмежених розмірів, до бажання всіх і все ганити» ${ }^{21}$. Загалом видання повинно було спонукати дослідників до більш детального вивчення окремих аспектів Української революції та українсько-більшовицького протистояння.

Збірник укладено за хронологічно-проблемним принципом. Документи згруповано у шість розділів. Для полегшення роботи з матеріалами на початку кожного розділу читачеві запропоновано схему й опис загального тла воєнних подій, а також короткий огляд військової операції, якій присвячено документи. Збірник також містить покажчики:

\footnotetext{
${ }^{20}$ Українсько-московська війна 1920 року в документах / 3 передм. і під ред. В. Сальського, упор. П. Шандрук. Ч. 1. Варшава. 1933. С. I.

${ }^{21}$ Українсько-московська війна 1920 року в документах... С. II.
} 
іменний, географічний та військових одиниць і частини. Видання доповнене різноманітними таблицями, схемами бойових дій і розташування військових підрозділів, їх передислокації під час операцій.

Оригінали опублікованих документів передали на зберігання у Бібліотеку імені С. Петлюри в Парижі. Варто зауважити, що це видання отримало чимало схвальних відгуків у наукових колах діаспори.

Таким чином, В. Сальський, окрім блискучої політичної та військової кар'єри, відзначився як і чудовий науковець і публіцист, критичний дослідник, фахівець 3 методології історії та хороший аналітик як процесів у минулому, так і тих подій, учасником яких він був безпосередньо. І це незважаючи на те, що з огляду на активну діяльність у сфері українського державотворення, зокрема, перебуваючи на посаді міністра військових справ, на повноцінну наукову роботу часу мав вкрай мало.

В. Сальський наполягав на тому, що історик має писати історію об'єктивно, не піддаючись політичній кон'юнктурі й особистим установкам. Особливо важливим застосування такого підходу він вважав у сфері військової історії, де науковцю варто було обмежитись лише констатацією фактів, та утриматися від будь-яких оціночних суджень. Загалом дослідник історії, згідно із В. Сальським, повинен був бути неупередженим, позбавленим симпатій чи антипатій до тої чи іншої персони чи події, уникати суб'єктивного досвіду при оцінці подій, політиків, військових діячів тощо, натомість опираючись у розвідках на якомога різноманітнішу та розлогішу джерельну базу, що відтворює проблему різнобічно та максимально всеохоплююче. При браку матеріалів, дав цінну пораду В. Сальський, науковцю варто би було обмежитись лише викладом усталених фактів. Чудовим зразком втілення таких порад стали й самі дослідницькі роботи діяча: «3 історії операцій Запорізької групи армії УНР влітку 1919 р», «Про оборону наших північних кордонів», «Старі мрії і нові пісні», «Українсько-московська війна 1920 року в документах». Хоч сам В. Сальський був активно залучений до процесів, про які писав, дослідження свої він проводив обєктивно та неупереджено, демонструючи свій критичний розум і науковий професіоналізм високого рівня.

\title{
Denys Kamentsev
}

\section{«Military history has no task at all to condemn». Volodymyr Salskyi: from understanding the methodology of history to trials in the scientific field}

\begin{abstract}
The purpose of the article is to reproduce on the main journalistic and memoir heritage of Volodymyr Salsky the transformation of his views on the understanding of the methodology of history and the evolution of his trials in the scientific field.

It is claimed that in the first half of the twentieth century, during the fateful historical changes, saturated with turbulent events: wars, political confrontations, regime changes, interest in historical narratives grew among the Ukrainian elite. Many public, political and military figures, realizing what an important time they had to live in, sought to join history. As a result, they became the authors of various memoirs, which reflected the events they wit-
\end{abstract}


nessed. Some public and especially military officials have tried their hand in the field of historical science. Among them was Volodymyr Salsky, a Ukrainian military figure, colonel of the General Staff, employee of General Yunakiv's department (1918), commander of the Zaporizhzhia group in the Kamyanets-Podilsky operation of the UPR (1919), and later cornet general of the UPR Army.

It is noted that V. Salskyi, in addition to a brilliant political and military career, distinguished himself as an excellent scientist and publicist, critical researcher, specialist in the methodology of history and a good analyst of both past processes and events in which he was directly involved. And this despite the fact that, given his active work in the field of Ukrainian state-building, in particular as Minister of War, he had very little time for full-fledged scientific work.

V. Salskyi insisted that the historian should write history objectively, without succumbing to the political situation and personal attitudes. He considered the application of such an approach especially important in the field of military history, where the scholar should confine himself to stating the facts and refrain from any evaluative judgments. In general, the researcher of history, according to V. Salskyi, should be impartial, devoid of sympathy or antipathy to a person or event, avoid subjective experience in assessing events, politicians, military figures, etc., instead relying in intelligence on the most diverse and more extensive source base, which reproduces the problem in many ways and as comprehensively as possible. In the absence of materials, V. Salskyi gave valuable advice, the scientist should limit himself to presenting the established facts.

An excellent examples of the implementation of such advice were the researcher's own research works: «From the history of operations of the Zaporozhzhia group of the army of the Ukrainian People's Republic in the summer of 1919», «On the defense of our northern borders», «Old dreams and new songs», «Ukrainian-Moscow war of 1920 in documents». Although V. Salskyi himself was actively involved in the processes he wrote about, he conducted his research objectively and impartially, demonstrating his critical mind and high-level scientific professionalism.

Keywords: Volodymyr Salskyi, military history, methodology of history, scientific heritage, journalism 